\title{
Hongo Atómico
}

\section{Atomic Mushroom}

\section{Pablo De Luca ${ }^{1} \quad$ Josefina Larralde ${ }^{1} \quad$ Alfredo Meyer $^{1}$}

${ }^{1}$ Servicio de Diagnóstico por imágenes, Hospital Italiano de La Plata, La Plata, Buenos Aires, Argentina

Rev Argent Radiol 2022;85(Suppl S1):S25.

Se presentó un paciente de 82 años con antecedentes de dislipemia e hipertensión arterial. Se le realizó una ecografía de pared abdominal por presentar dolor de 24 horas de evolución, asociado a una masa supraumbilical, sin nauseas ni vómitos.

En la ecografía de la región descripta (-Fig. 1), con trasductor lineal de 7,5 Mhz, se visualiza a la realización

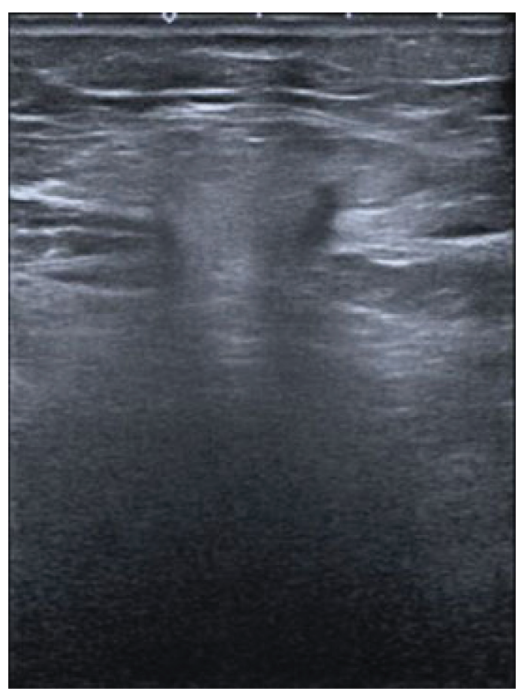

Fig. 1 Corte transversal en topografía supraumbilical, donde se observa saco herniario con contenido graso abdominal y cuello herniario.
Address for correspondence Pablo De Luca, Servicio de Diagnóstico por imágenes, Hospital Italiano de La Plata, La Plata, Buenos Aires, Argentina (e-mail: pablodeluca4@gmail.com).

de la maniobra de Valsalva el pasaje del contenido graso abdominal a través de la línea blanca, conformando una imagen que da el aspecto del hongo generado por la explosión de una bomba atómica (-Fig. 2). Se identifica el saco herniario en el plano graso como la masa gaseosa que se dispersa en el cielo, y al cuello herniario con la apariencia del tallo de humo.

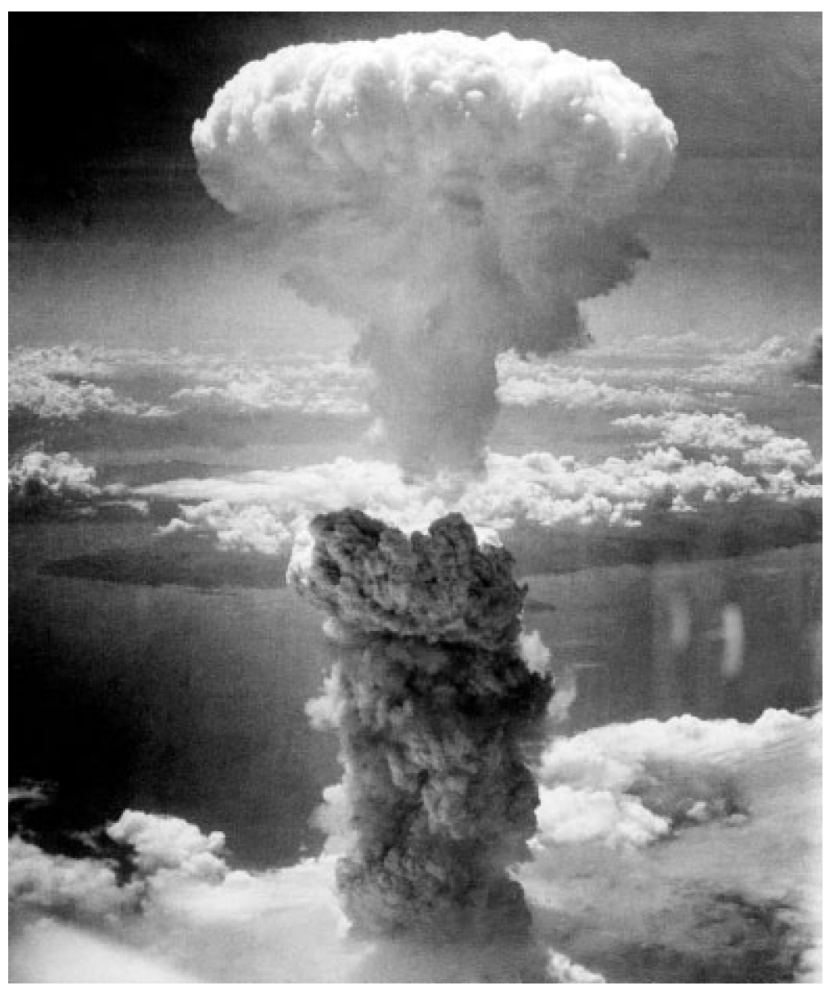

Fig. 2 Hongo atómico.

(C) 2019. Asociación Civil Sociedad Argentina de Radiología and Federacion Argentina de Asociaciones de Radiología, Diagnóstico por Imágenes y Terapia Radiante. All rights reserved.

This is an open access article published by Thieme under the terms of the Creative Commons Attribution-NonDerivative-NonCommercial-License, permitting copying and reproduction so long as the original work is given appropriate credit. Contents may not be used for commercial purposes, or adapted, remixed, transformed or built upon. (https://creativecommons.org/ licenses/by-nc-nd/4.0/)

Thieme Revinter Publicações Ltda., Rua do Matoso 170, Rio de Janeiro, RJ, CEP 20270-135, Brazil 